\section{Gordana Gavric ${ }^{1}$}

Faculty of business economics and entrepreneurship

\section{Snezana Kirin ${ }^{2}$}

University of Belgrade

Innovative center, Faculty of mechanical engineering,

\section{Marija Cukanovic Karavidic ${ }^{3}$}

Faculty of business economics and entrepreneurship
SCIENTIFIC REVIEW ARTICLE doi:10.5937/ekonomika1604115G

Received: August 17, 2016 Accepted: November 25, 2016

\title{
ADAPTABILITY OF COMPANIES IN THE REPUBLIC OF SERBIA - EMPIRICAL RESEARCH
}

\begin{abstract}
In an era of constant change in all spheres of business, an essential factor in the survival of a company is monitoring developments in the region, rapid response to current trends and anticipating future market developments. In this way, companies become more successful and have more proactive control of their future.

The aim of paper was that through empirical research, did on the model of Denison, shows the degree of adaptability of enterprises in the Republic of Serbia, to identify the factors that influence its development and check the premise that innovation is an essential factor of adaptability. Difference in adapting to changes in domestic and foreign companies is also analyzed. The results showed that companies in the Republic of Serbia still need to work on improving the adaptability, that the certain aspects of adaptability are more present in foreign than in domestic companies and that innovation is the main factor of adaptability. The significance of the results is in determining the way of improving the functioning of companies in the Republic of Serbia, especially of domestic companies, which after a period of transition, trying to integrate successfully into the European and world economy.
\end{abstract}

Keywords: adaptability, companies, Serbia, Denison model

JEL Classification: L20

\section{АДАПТИБИЛНОСТ ПРИВРЕДНИХ ДРУШТАВА У РЕПУБЛИЦИ СРБИЈИ-ЕМПИРИЈСКО ИСТРАЖИВАЫЕ}

\begin{abstract}
Apstrakt
У ери сталних промена у свим сферама послована, битан фактор опстанка привредног друштва је праћење дешавања у окружењу, брза реакиија
\end{abstract}

\footnotetext{
${ }^{1}$ gordana.gavric.bg@gmail.com

${ }^{2}$ snezanakirin@yahoo.com

${ }^{3}$ cukanovickaravidicmarija@gmail.com
} 
на актуелне трендове и антиципирање будућих дешавања на тржишту. На тај начин компаније постају успешније и имају проактивнију контролу над својом будућношћу.

Циљ рада је био да кроз емпиријско истраживање, урађено по моделу Денисона, прикаже степен адаптибилности привредних друштава у Републици Србији, да се идентификују фактори који на юу утичу и провери предпоставка по којој је иновативност битан фактор адаптибилности. Анализирана је и разлика у адаптирању променама у домаћим и страним компанијама. Резултати су показали да привредна друштва у Републици Србији још треба да раде на унапређењу адаптибилности, да су одређени аспекти адаптибилности више присутни у страним него у домаћим компанијама и да иновативност јесте главни фактор адаптибилности. Значај добијених резултата је у одређивању праваца унапређења деловања привредних друштава у Републици Србији, посебно домаћих привредних друштава која након периода транзиције покушавају да се успешно уклопе у европске и светске привредне токове.

Кључне речи: адаптибилност, привредна друштва, Србија, Денисонов модел

\section{Introduction}

"The 1990s may witness the beginning of the end of the traditional organization" (Nadler, Gerstein, Shaw et al, 1992, p. 263) and the beginning of the time in which changes are the key for the survival and growth. New business conditions require a new organizational behavior. "The relevant criterion is not the size, but the strength and, above all, the power to adjust" (Frank, 2015, p. 217).

Adaptability has become the most desirable characteristic and the primary activity of companies that think responsibly about their future. "History has repeatedly shown that individuals and institutions who are able to quickly adapt and to change, have the best results in terms of social change and difficult circumstances" (Jašarević, 2012, p. 179). Adaptability, therefore, is not the trait of a new era, but the need for it is more intense than ever. "Conditions, in which organizations operate demand a response without which organizational demise is a frequent result" (Cameron, Quinn, 2006, p. 7). In the years to come, when is, according to the words of Hamel and Brin "competitive anarchy is on the rise" (p. 22), the degree of organizational adaptability, as well as people and society as a whole, will be seriously tested.

The aim of this paper is to show the degree of adaptability of enterprises in the Republic of Serbia, to identify factors that affect adaptability and to analyze adaptability differences in local and in foreign companies through empirical research. As specified by Denison model, according to which the research was conducted and results presented in this work, adaptability is a flexibility factor of companies' organizational culture. By adaptability improving the organizational culture is being developed and modernized. Adaptability is a phenomenon that in time when almost all resources are relatively equally accessible, provide companies with a truly unique competitive advantage (Arikan, Enginoglu, 2016). 


\section{The phenomenon of adaptability}

The presence of constant competition and an organization's need of to survive and exist on the world market require it to have the ability and willingness to constantly change and adapt in order to successfully overcome uncertainty and competition. Attitude of an organization towards changes, as well as towards occasional disturbances that briefly disrupt balance in an otherwise peaceful and stable business world, will expose every organization to a high risk. Stephen P. Robbins and Timothy A. Judge (2009) in their book Organizational Behaviour, call such organizations arrogant organizations because they quickly lose their competitive advantage due to their attitude, emphasizing that corporate highway is filled with wrecks of companies which have allowed arrogance to undermine their earlier successes. It is likely that some of these companies will eventually recover and stand up on their feet again, but millions of dollars and customers might have been lost forever, which is the high price they paid for their lack of adaptability.

Peter Drucker (2005) also points out that a "modern organization has to become a generator of changes and to organize abandonment of things that have proven to be surpassed, as well as to continually work to improve all products, services and processes within itself" (p. 213).

"Successful organizations use more ideal forms of organizational structures and processes that enable them to become more organizationally flexible and adaptable, and to generate amazing products and services. It gives them more proactive control over their future instead of waiting to react to change in their marketplace" (Ackoff, Magidson, Addison, 2006, p. 139).

In order to increase their ability to adapt, and become competitive or to gain advantage over others (Coulter, 2010), organizations must encourage their employees to use their own intellectual and creative potential more fully, to change, and to take risks; it has to support employees' initiative, and to motivate collaboration among employees... For example, a research conducted in 1994, among business people from different industries, showed that employees spend only 5 to 15 percent of their time thinking, learning and innovating in their organizations (Goldman, Nagel, Preiss, 1995). Today, it is not enough. Thinking, learning and innovation are not only an obligation of top management, but the task of all employees. Waking of creativity in people can literally change direction of an organization and bring stunning results. "It is the first step of innovation, and innovation is the driving force of the creation of wealth" (Veselinović, Rosić, Stojanović, 2014, p. 72). Investment in human capital is the most effective one a modern organization can make. "An average $10 \%$ increase in education among employees will increase overall productivity by around $8.6 \%$, while the increase in capital equipment by $10 \%$ increases productivity by 3.4\%" (Stefanović, Vojnović, Urošević, 2012, p. 71). In order to improve productivity and work and to take a better position in the market, organizations are nowadays ready to make some trade-offs. In 2012, approximately three-quarters (77\%) of employers in the United States allowed some employees to change the time of starting/ending their work and $63 \%$ allow them to carry some tasks out and to work from home (Matos K, E. Galinsky, 2012). If we consider famous words of Bill Gates that "each morning, ninety percent of a company's value walks in, and walks out in the afternoon" (Jovičić, Jovičić, 2015, p. 196), it is clear that any adaptability to modern circumstances in terms of improving human resource management activities beneficial to the organization. 
Adaptable organizations place their business focus on customers. Unless a company is not owned by the state, a relationship that employees have towards consumers is an important success factor nowadays. The Amazon company can serve as an example of those whose work is marked by a relentless striving to achieve a greater benefit to its customers. That way was born one of the leading e-commerce platform, Amazon.com, that offers book fans from all over the globe an opportunity to look for and buy books from the comfort of their armchairs, choosing in peace among more than million titles. On the other hand, Nokia, once the strongest brand in the field of mobile telephony, fell from the throne due to the fact that it failed to devote enough attention to the specific needs of its customers. Dell has become the world's largest PC vendor, thanks to the fact that it "constantly re-conceived and outwitted its competitors" (Robbins, Judge, 2009, p. 23 ), offering the best to its consumers.

Thus, we can conclude that "in the modern environment, which is subject to frequent changes, an organization, if it wants to remain equal to the competition, must develop a system of organizational response to all relevant changes in real time" (Stefanović, Jaško, Damnjanović, 2010, p. 4). Kodak Company has held on its competitiveness thanks to the fact that their "leadership equipped themselves with the adequate flexibility needed to respond quickly to business environmental changes" (Jovanović, 2015, p. 147). There is a trend that "it is believed that organizations will be given a new name in the future mutable organizations" (Ristić et al, 2007, p. 95). Therefore, for an organization that in the twenty-first century praise its constancy in business, sameness of its products or the status quo, we can freely say that it is in a period of stagnation, rather than it is stable and prosperous.

\section{Research methodology and basic hypothesis}

Adaptability of companies in Republic of Serbia which, according to Denison model means creating change, organizational learning and focus on consumers, was tested through research conducted by technique of written interviewing. A questionnaire in the form of Likert scale for measuring attitudes $(1-$ completely disagree, 2 - partly disagree, 3 - neither agree nor disagree, 4 - partly agree, 5 - completely agree), constructed according to Denison's model (Denison, Neale, 1999) with slight modification of attitudes, was used for data collection. The questionnaire was distributed in direct contact with respondents and via social network Facebook. Data were analyzed and interpreted using the program IBM SPSS Statistics 21. Given study is a part of the research about organizational cultures in companies in Serbia, conducted for the purpose of the doctoral thesis.

In order to elucidate factors of adaptability in Serbian companies, we have conducted a research on a sample of 1,000 respondents employed in domestic and foreign companies in 29 cities in Serbia. The survey was conducted in the period from November 2014 to November 2015.

Examined attitudes:

- The way things are done is very flexible and easy to change

- We respond well to competitors and other changes in the business environment 
- New and improved ways to do work are continually adopted

- Attempts to create change seldom meet with resistance

- Different parts of the organization often cooperate to create change

- Customer wants and needs are being mentioned and have directly influence on decisions and business

- We encourage direct contact with customers by our people

- We view failure as an opportunity for learning and improvement

- Innovation and risk taking are encouraged and rewarded

- Learning is an important objective in our day-to-day work

- We are familiar with the work of other sectors at all times

Basic research hypotheses are:

1. Companies in Serbia support adaptability.

2. There are some differences of opinion about the degree of adaptability in domestic and foreign companies.

3. Innovation is the essential factor of adaptability.

To test the hypothesis 1, which aims to analyze the adaptability of companies, a descriptive analysis was used. To test the hypothesis 2 , which aims to analyze the similarities and differences in the degree of adaptability in the organization of domestic and foreign companies, we applied the t-test for independent samples and to determine the important factors of adaptability we used factor analysis, Extraction Method: Principal Component Analysis with Rotation Method: Varimax with Kaiser Normalization.

\section{Research sample}

The study included 1000 respondents employed in micro (20\% respondents), small $(17,1 \%$ respondents), medium $(33,8 \%$ respondents) and large companies $(29,1 \%$ respondents) in the Republic of Serbia.

Regarding to activity of the company, most of the employees work in the company which is engaged in other service activities $20,4 \%$, in field of public administration and compulsory social security work $17,8 \%$ of respondents, in production $14 \%$, in field of education $11,6 \%, 8,4 \%$ work in financial area and are of insurance activities, $6,6 \%$ respondents work in field of transport and storage, $4,7 \%$ respondents work in companies which is engaged in field of accommodation and food services, from field of health and social work are 4,3\% respondents, in field of information and communication work 3,9\% respondents, from companies engaged in administrative and support service activities are $3,6 \%$ respondents, in field of professional, scientific, innovative an technique activities are $2,6 \%$ respondents, in field of arts, entertainment and recreation work $1,9 \%$ of employees and in companies engaged in real estate work $0,2 \%$ respondents. Classification of activities are arranged according to the Government Regulation of Classification of Activities from 2010.

Most of the employees, who took part in research, work in domestic companies, $86 \%$, and the rest of examinees work in foreign companies, $14 \%$.

According to owned company, more than a half of employees (52\%) are from private companies, $44 \%$ respondents are from state companies and $4 \%$ work in social companies. 
According to their work position, there were the most workers, $64 \%$, then lowlevel managers, 19\%, middle-level managers were $9 \%$ and top managers $8 \%$.

\section{Empirical research}

Table 1 presents data of the central tendency (mean) and standard deviation relating to attitudes that describe the adaptability, for a sample size of $\mathrm{N}=1,000$ respondents and Likert scale for measuring attitudes.

Table 1. Reviews of the attitudes of the factor 'adaptability'

\begin{tabular}{|l|c|c|}
\hline & Mean & Std. Deviation \\
\hline Way flexible and easy & 3,27 & 1,233 \\
\hline Respond well & 3,63 & 1,153 \\
\hline New, improved ways & 3,54 & 1,173 \\
\hline Attempts resistance & 3,29 & 1,154 \\
\hline Parts cooperate & 3,42 & 1,147 \\
\hline Customer wants and needs & 3,55 & 1,229 \\
\hline Encourage contact & 3,82 & 1,173 \\
\hline Failure & 3,53 & 1,197 \\
\hline Innovation and risk & 3,25 & 1,269 \\
\hline Learning & 3,72 & 1,277 \\
\hline Familiar with work & 3,51 & 1,263 \\
\hline Average & 3,5 & \\
\hline
\end{tabular}

According to the results, we can see that the average score of all examined attitudes related to adaptability, in companies in Serbia is approximately 3.5, which is a value between 3-neither agree nor disagree and 4-partly agree Likert scale and somewhat higher than the mean value.

To test the difference between the mean values in terms of attitudes that describe adaptability in domestic and foreign companies, we applied again t-test for independent samples whose group statistics given in Table 2. Number of respondents which work in domestic companies is $\mathrm{Nd}=859$, while the number of respondents employed in foreign companies is $\mathrm{Ns}=141$. 
Table. 2. Description of attitudes on adaptability in domestic and foreign companies

\begin{tabular}{|c|c|c|c|c|c|}
\hline \multicolumn{6}{|l|}{ Group Statistics } \\
\hline \multicolumn{2}{|c|}{ CompanyDomesticForeign } & \multirow{2}{*}{$\begin{array}{c}\mathrm{N} \\
859\end{array}$} & \multirow{2}{*}{$\begin{array}{r}\text { Mean } \\
3,27\end{array}$} & \multirow{2}{*}{$\begin{array}{c}\begin{array}{c}\text { Std. } \\
\text { Deviation }\end{array} \\
1,234\end{array}$} & \multirow{2}{*}{$\begin{array}{c}\begin{array}{c}\text { Std. Error } \\
\text { Mean }\end{array} \\
, 042\end{array}$} \\
\hline Way flexible and easy & domestic & & & & \\
\hline & foreign & 141 & 3,26 & 1,233 &, 104 \\
\hline \multirow[t]{2}{*}{ Respond well } & domestic & 859 & 3,61 & 1,160 & 040 \\
\hline & foreign & 141 & 3,77 & 1,104 & ,093 \\
\hline \multirow[t]{2}{*}{ New, improved ways } & domestic & 859 & 3,51 & 1,173 & ,040 \\
\hline & foreign & 141 & 3,73 & 1,158 & ,098 \\
\hline \multirow[t]{2}{*}{ Attempts resistance } & domestic & 859 & 3,28 & 1,168 & 040 \\
\hline & foreign & 141 & 3,38 & 1,067 & 090 \\
\hline \multirow[t]{2}{*}{ Parts cooperate } & domestic & 859 & 3,40 & 1,154 & 039 \\
\hline & foreign & 141 & 3,57 & 1,091 & ,092 \\
\hline \multirow[t]{2}{*}{ Customer wants and needs } & domestic & 859 & 3,51 & 1,239 &, 042 \\
\hline & foreign & 141 & 3,79 & 1,145 & ,096 \\
\hline \multirow[t]{2}{*}{ Encourage contact } & domestic & 859 & 3,78 & 1,163 &, 040 \\
\hline & foreign & 141 & 4,02 & 1,216 & , 102 \\
\hline \multirow{2}{*}{ Failure } & domestic & 859 & 3,53 & 1,211 & 041 \\
\hline & foreign & 141 & 3,50 & 1,112 & ,094 \\
\hline \multirow{2}{*}{ Innovation and risk } & domestic & 859 & 3,26 & 1,269 & 043 \\
\hline & foreign & 141 & 3,19 & 1,276 & , 107 \\
\hline \multirow{2}{*}{ Learning } & domestic & 859 & 3,73 & 1,275 & 044 \\
\hline & foreign & 141 & 3,61 & 1,286 &, 108 \\
\hline \multirow[t]{2}{*}{ Familiar with work } & domestic & 859 & 3,49 & 1,261 & 043 \\
\hline & foreign & 141 & 3,62 & 1,274 &, 107 \\
\hline
\end{tabular}

In the third column in the table 2 is mean value of adaptability, for all attitudes, in domestic and foreign companies. The obtained values are between 3 (neither agree nor disagree) and 4 (partly agree). The fourth column shows standard deviation from mean value and fifth column shows standard error of mean value.

Average values of all tested attitudes about adaptability are 3.49 for domestic companies, and little more, 3.59 , for foreign companies. 
Table 3. Adaptability: t-mecm

\begin{tabular}{|c|c|c|c|c|c|c|c|c|c|c|}
\hline \multicolumn{11}{|c|}{ Independent Samples Test } \\
\hline & & \multicolumn{2}{|c|}{$\begin{array}{l}\text { Levene's Test } \\
\text { for Equality of } \\
\text { Variance }\end{array}$} & \multicolumn{7}{|c|}{ t-test for Equality of Means } \\
\hline & & \multirow[t]{2}{*}{ F } & \multirow[t]{2}{*}{ Sig. } & \multirow[t]{2}{*}{$\mathrm{t}$} & \multirow[t]{2}{*}{ df } & \multirow[t]{2}{*}{$\begin{array}{l}\text { Sig. } \\
\text { (2-tailed) }\end{array}$} & \multirow[t]{2}{*}{$\begin{array}{l}\text { Mean } \\
\text { Difference }\end{array}$} & \multirow{2}{*}{$\begin{array}{l}\text { Std. } \\
\text { Error } \\
\text { Difference }\end{array}$} & \multicolumn{2}{|c|}{$\begin{array}{l}\text { 95\% Confidence } \\
\text { Interval of the } \\
\text { Difference }\end{array}$} \\
\hline & & & & & & & & & Lower & Upper \\
\hline $\begin{array}{l}\text { New, improved } \\
\text { ways }\end{array}$ & $\begin{array}{l}\text { Equal } \\
\text { variances } \\
\text { assumed }\end{array}$ & 1,41 & 0,24 & $\begin{array}{l}-2 \\
12\end{array}$ & 998,00 & 0,04 & $-0,23$ & 0,11 & $-0,43$ & $-0,02$ \\
\hline $\begin{array}{l}\text { Customer wants } \\
\text { and needs }\end{array}$ & $\begin{array}{l}\text { Equal } \\
\text { variances } \\
\text { assumed }\end{array}$ & 4,60 & 0,03 & $\begin{array}{l}-2 \\
59\end{array}$ & 197,75 & 0,01 & $-0,27$ & 0,11 & $-0,48$ & $-0,07$ \\
\hline $\begin{array}{l}\text { Encourage } \\
\text { contact }\end{array}$ & $\begin{array}{l}\text { Equal } \\
\text { variances } \\
\text { assumed }\end{array}$ & 0,96 & 0,33 & $\begin{array}{l}-2 \\
25\end{array}$ & 998,00 & 0,03 & $-0,24$ & 0,11 & $-0,45$ & $-0,03$ \\
\hline
\end{tabular}

Table 3 shows the results of t-test for independent samples. The first part of the table shows the results of Leven's test of variances equality. The outcome of this test determines whether the t-value is used when it implies the equality of variance (Sig $>$ $0.05)$ or t-value, when it does not imply the equality of variance $(\mathrm{Sig}<0.05)$.

The test results show that there is a statistically significant difference in the attitudes "New and improved ways to do work are continually adopted"; "Customer wants and needs are being mentioned and have directly influence on decisions and business"; and "We encourage direct contact with customers by our people", in favor of foreign companies (Figure 1), while there are no statistically significant differences when it comes to other attitudes related to adaptability.

On the basis of the survey results we can conclude that foreign companies pay more attention to consumers than domestic companies. 
Figure 1. Statistically significant results of the t-test-adaptability

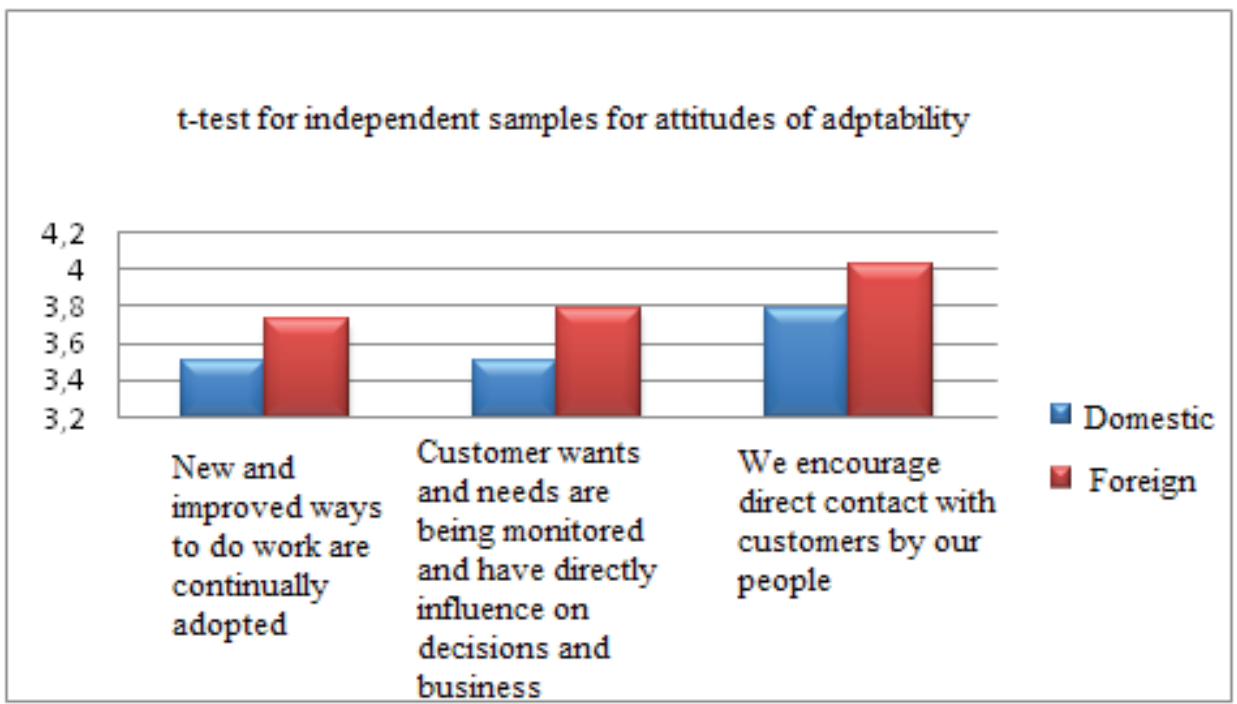

\section{Determining the major factors of employees' involvement}

In order to determine the main factors influencing the adaptability of company, we applied the factor analysis on a set of variables shown in the first column of Table 5. The extraction method of the main factors was used (Extraction Method: Principal Component Analysis, (PCA)).

Table 4. KMO and Bartlett's Test-adaptability

\begin{tabular}{|c|c|c|}
\hline \multicolumn{3}{|c|}{ KMO and Bartlett's Test } \\
\hline \multicolumn{2}{|c|}{ Kaiser-Meyer-Olkin Measure of Sampling Adequacy. } & 879 \\
\hline \multirow{3}{*}{ Bartlett's Test of Sphericity } & Approx. Chi-Square & 8527,131 \\
\hline & df & 210 \\
\hline & Sig. & 000 \\
\hline
\end{tabular}

Since $\mathrm{KMO}=0,879>0,6$ and the level of significance $\mathrm{Sig}<=0,000<0,05$, table 4 , the condition for applying the method is justified.

After extraction, we took 6 factors into consideration that explain $64,3 \%$ of the variance whereby individual factors explain about $31,59 \%, 9,63 \%, 7,2 \%, 6 \%, 5 \%$ and $4,8 \%$ of variance, respectively.

After applying Varimax rotation with Kaiser Normalization (Rotation method: Varimax with Kaiser Normalization), we got the results shown in Table 5. 
Table 5. Rotated Component Matrix-adaptability

\begin{tabular}{|c|c|c|c|c|c|c|}
\hline \multicolumn{7}{|c|}{ Rotated Component Matrix ${ }^{a}$} \\
\hline & \multicolumn{6}{|c|}{ Component } \\
\hline & 1 & 2 & 3 & 4 & 5 & 6 \\
\hline New, improved ways & ,794 &,- 084 & 016 & 068 &,- 002 &,- 060 \\
\hline Innovation and risk & ,786 &,- 010 &,- 094 &,- 062 & 002 & ,052 \\
\hline Failure & ,782 &,- 013 &,- 110 &,- 053 &,- 105 & 049 \\
\hline Learning & ,768 &, 013 &,- 092 &,- 093 & 024 & 127 \\
\hline Respond well & ,766 &,- 147 &, 117 & 042 &,- 008 &,- 136 \\
\hline Familiar with work & ,758 &,- 074 &,- 104 &, 001 &, 067 &,- 045 \\
\hline Parts cooperate & ,757 &,- 093 &,- 006 & ,070 &, 101 &,- 007 \\
\hline \begin{tabular}{|l}
$\begin{array}{l}\text { Customer wants and } \\
\text { needs }\end{array}$ \\
\end{tabular} & ,737 &,- 045 &,- 066 & , 142 & 017 &,- 003 \\
\hline Encourage contact &, 724 &,- 025 &,- 114 & 163 & 025 & ,020 \\
\hline Attempts resistance & ,719 &,- 082 &, 033 &,- 007 & 089 & ,094 \\
\hline Way flexible and easy & 680 &,- 004 &,- 105 &,- 002 & ,098 &,- 141 \\
\hline Years of service &,- 132 & ,922 &, 015 &,- 046 & 035 & ,002 \\
\hline Age &,- 129 & ,920 &,- 071 &,- 106 & ,006 & ,046 \\
\hline Company size &,- 185 &, 191 & ,739 & ,166 & ,080 & 075 \\
\hline Work position &,- 125 &,- 353 & 624 &,- 087 & ,092 & , 140 \\
\hline Level of education &,- 095 & ,133 &,- 481 &,- 039 & 256 & ,219 \\
\hline Company ownership & 015 &,- 056 &, 151 & 918 & 004 & ,027 \\
\hline Ownership structure &,- 212 &, 228 &, 560 &,- 604 &,- 006 &,- 076 \\
\hline City &,- 127 &,- 026 & ,098 & 039 &,- 710 & ,324 \\
\hline Company activity & 060 &,- 005 & 075 & 041 & 681 & ,229 \\
\hline Gender & 033 & 022 & 002 & 048 & 009 & ,881 \\
\hline
\end{tabular}

By the analysis of the results we have selected 6 main factors which affecting adaptability and that are shown on Figure 2:

Factor 1: Innovation

Factor 2: Experience

Factor 3: Size of an organization and position in it

Factor 4: The origin of an organization and ownership

Factor 5: Activities of a company and city

Factor 6: Gender

The largest contribution to the explanation of variance gives us the first factor, presented as Innovation, about $31.6 \%$. 
Figure 2. Factors affecting adaptability

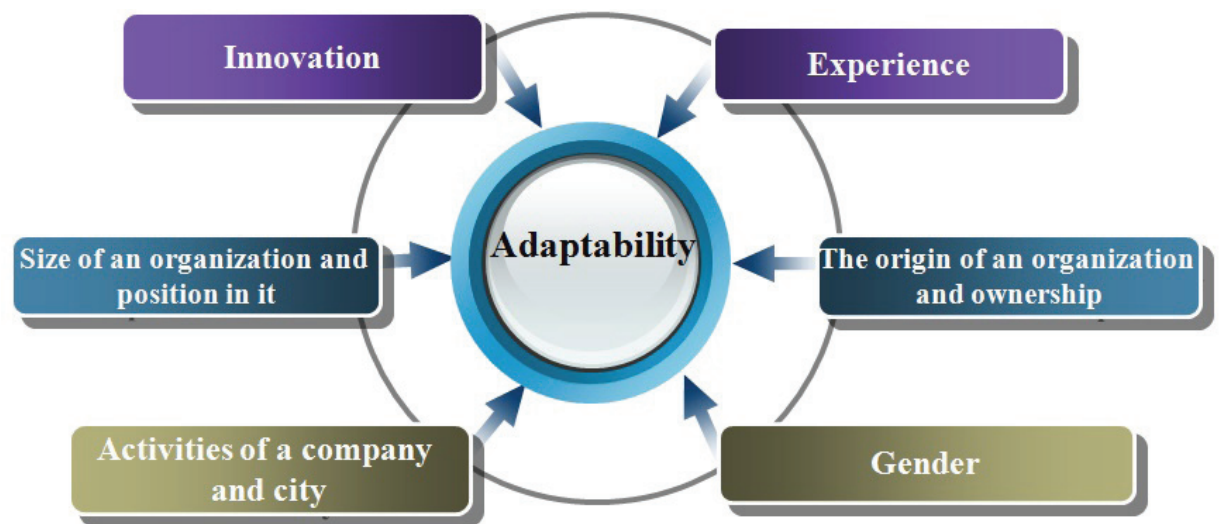

\section{Results of research}

The first hypothesis, that companies in Serbia support adaptability, is partially confirmed because obtained score 3.50 represents a value that is slightly larger than "yes or no" and less than "I partly agree". This shows that companies in Serbia need to work on adaptability in all areas of business in a manner that is more responsive to changes.

The second hypothesis, which refers to difference in attitudes about a degree of adaptability in domestic and foreign companies is partly confirmed, because the result of research shows that new and improved ways of working are constantly acquired in foreign companies that better meet the needs and desires of consumers, and therefore directly affect decisions and operations. Foreign companies more often encourage direct contact with customers. Noted differences can serve as a way to improve the functioning of domestic companies.

The third hypothesis, which argues that innovation is an essential factor of adaptability, is fully confirmed, because innovation is obtained as the main factor in a company's adaptability as ability to continually create and adopt new ways of work.

\section{Conclusion}

The challenges that came along with the process of globalization, primarily related to global competition, put a tremendous pressure on organizations. In their work, enterprises face significant risks and instability of occupied positions. It becomes increasingly difficult to be competitive. Changes that were once sporadic and rare, are now constant, rapid, sudden and unexpected. Success is on the side of those who are able to look at business opportunities that provide quick and adequate response to all challenges, solve problems in innovative ways, constantly offering new products and services, to adequate and timely respond to the challenges of competition and thus more quickly reach their consumers. In a word, an advantage is on the side of those who have a high capacity for adaptability. 
The presented research enabled to examine the adaptability of companies in the Republic of Serbia, and on that basis determine the direction of improving their functioning. Also, in the country where until a few decades ago, foreign companies were not present in the country, and comparing business models used in them is special useful in order to improve effectiveness and efficiency of domestic companies.

The significance of research and obtained results is in fact that Republic of Serbia as the country that recently came out of transition and experienced deindustrialization now tries to join successfully in the European and world economy.

\section{References}

Ackoff, L. R., Magidson, J., \& Addison, J. H. (2006). Idealized design; creating an organization's future. New Jersey, Wharton School Publishing

Arikan C. L., \& Enginoğlu D. (2016). How elements of corporate culture affect overall firm performance. International Journal of Business Management and Economic Research (IJBMER), Vol 7(3), 680-689

Cameron, S. K.,\& Quinn, E. R. (2006). Diagnosing and changing organizational culture; Based on competing values framework, revised edition. San Francisco, The Jossey-Bass A Wiley Imprint

Coulter, M. (2010). Strategijski menadžment na delu, forth edition. Beograd: Data status

Denison, R. D., \& Neale, S. W. (1999). Denison Organizational Culture Survey, Facilitator Guide, Retrieved October 20, 14., from http://www.denisonconsulting. com/Docs/DOCS A-Z/DOCS Facilitator Guide.Pdf,

Draker, P. (2005). Upravljanje u novom društvu. Novi Sad: Adižes

Frank, A. (2015). Menadžment-učite od najboljih. Beograd: Laguna

Gavrić, G. (2016). Organizaciona kultura kao faktor rasta i razvoja privrednog drustva. Neobjavljena doktorska disertacija, Fakultet za primenjeni menadžment, eknomiju i finansije, Univerzitet Privredna akademija u Novom Sadu

Goldman L. S., Nagel N. R., \& Preiss K. (1995). Agile competitors and virtual organizations; strategies for enriching the customer Van nostrand reinhold, USA: A division of international Thomson publishing Inc.

Hamel, G.,\& Brin, B. (2009). Budućnost menadžmenta. Novi Sad: Asee

Jašarević S. (2012). Fleksibilizacija rada - rešenje ili zabluda. Zbornik radova Pravnog fakulteta u Novom Sadu, 4, 173-192

Jovanović, Z. (2015). Management and changes in business environment. Ekonomika, Vol. 61, № 2, 143-151

Jovičić M., \& Jovičić A. (2015). Inovacije i konkurentska prednost. Anali Ekonomskog fakulteta u Subotici, Vol. 51, broj 33, 193-202

Matos K., \& Galinsky E. (2012). “2012 National Study of Employers, ” Families and Work Institute, Retrieved February 2016 from < http://familiesandwork.org/site/ research/reports/NSE_2012.pdf>. 
Nadler, A. D., Gerstein S. M., Shaw B. R. \& associated (1992). Organizational architecture; designs for changing organizations, paper Gerstein S. Marc, Shaw B. Robert, Organizational Architectures for Twenty-First Century (pp. 263-273). San Francisco: Jossey-Bass Publishers

Robbins,P. S.,\& Judge,A. T. (2009). Organizaciono ponašanje, 12th edition. Zagreb: Mate

Ristić, D. \& saradnici (2007). Upravljanje promenama. Novi Sad: Cekom books

Stefanović I., Jaško O., \& Damnjanović P. (2010). Analiza prirode savremenog organizacionog okruženja. Industrija, vol. 2, 23-43

Stefanović V., Vojnović B., \& Urošević S. (2012). Menadžment ljudskih resursa; savremene strategije i kontroverze. Beograd: Institut za ekonomiku poljoprivrede

Veselinović, P., Rosić, B., \& Stojanović, M. (2014). Intelektualni kapital u funkciji inovativnosti i konkurentnosti nacionalne ekonomije. Ekonomika, broj 1, 69-83 